\title{
The Impact Of Tax Planning On Firm Value
}

\author{
Shella Angelina ${ }^{\mathrm{a}}$, Arif Darmawan ${ }^{\mathrm{b}, *}$ \\ ${ }^{a}$ Managerial Accounting, Politeknik Negeri Batam, shellaangelina5712@gmail.com \\ ${ }^{\mathrm{b}}$ Managerial Accounting, Politeknik Negeri Batam, darmawan@ polibatam.ac.id
}

\begin{abstract}
The purpose of this research to determine the effect of tax planning that is measured using Cash ETR and Book Tax Difference (BTD) on company value. In addition to that, the purpose of doing tax planning is also to streamline corporate tax expenditures following applicable regulations, so that with the existence of corporate tax planning can estimate the company's tax expenses. This study uses the dependent variable that is the value of the company that is proxy using Tobins' $Q$ while the independent variable is tax planning which is proxy using Cash ETR and Book Tax Different. The control variables used in this study are Size and Leverage. The samples used in this study were all manufacturing sector companies in a row from 2016 to 2018 with a total sample of 135 companies for 3 consecutive years. This study uses the Eviews 9 test tool and uses a multiple regression test. The results of this study indicate that Cash ETR has a positive effect on firm value while Book Tax Different has a negative effect on firm value.
\end{abstract}

Keywords: Cash ETR, Book Tax Difference (BTD), Tobins'Q, Tax Planning, Firm Value

*Corresponding author. E-mail: darmawan@ polibatam.ac.id 


\section{Introduction}

Every company must try to achieve its goals by increasing the value of the company. Increasing and decreasing company value greatly affects the level of prosperity of shareholders. The high value of the company illustrates the increase in the wealth of shareholders, and the low value of the company also shows the lower level of prosperity that will be obtained by shareholders. Companies must be able to process limited resources and be able to optimize productivity to increase the value of the company, one of the ways to manage tax expenses.

Company value is the result of management's work which includes net cash flow, growth, and capital costs. The component of company value is the share price. The high price per share will produce good corporate value (Herawati \& Titin, 2013). The importance of company value for a company is due to the reflection of the stock price and shows the company's selling price. Besides, the value of the company shows the state of achievement of the company from management to illustrate the trust of the community by going through the process of activities from the establishment until now (Noerirawan, 2012).

One way to optimize company value is to manage tax expenses. For companies, taxes can be used as a deduction from income. The greater the income, the greater the tax burden that must be paid, so that it will affect the amount of profit after tax that will be received by the company. When company profits after tax have decreased, this will affect the value of the shares so that the value of the company also decreases. Companies are advised to do tax planning (Tax Planning) to minimize the amount of tax legally by not violating taxation rules.

Tax planning (tax planning) is an organizing effort for individual and corporate taxpayers to be able to take advantage of loopholes in terms of minimizing the tax burden in line with applicable regulations (Pohan, 2013). Tax planning is carried out through careful analysis and the utilization of opportunities or opportunities in the regulations set by the government. The main purpose of tax planning is to make the tax burden borne following tax regulations. It can be interpreted that tax planning is done to save taxes by utilizing the provisions outside the tax regulations. This was done not to evade, but to adjust the actual tax amount.

Another benefit obtained from tax planning is that it is easy to regulate cash flow so that the cash budget can be arranged more accurately. The importance of this research is to examine how tax planning affects company value, as well as to generalize perceptions in previous research.

This research has been examined in Indonesia by Pradyana \& Noviari (2017) which states that the variable tax planning affects the value of the company with company transparency as a moderating variable to support this effect. Apart from that, other researchers prove that tax planning has a positive effect on firm value (Lestari, 2014).

This research has been examined in Indonesia by Pradyana \& Noviari (2017) which states that the variable tax planning affects the value of the company with company transparency as a moderating variable to support this effect. Apart from that, other researchers prove that tax planning has a positive effect on firm value (Lestari, 2014).

Research conducted by Pandu \& Achmad (2017) states that there is a positive relationship between proxied tax planning and ETR ratio and firm value is proxied using Tobins'Q. Other supportive research also conducted by Hidayat \& Pesudo (2019) revealed that tax planning has a positive effect on firm value, managerial ownership has a negative effect on firm value, and corporate transparency moderates the relationship between tax planning and managerial ownership on firm value.

Noviani (2017) states that tax planning variables have a negative influence on firm value, earnings management variables affect company value, institutional ownership variable does not affect company value, managerial ownership variable does not affect company value, independent commissioner variable has an influence on firm value, and audit quality variables influence firm value.

Yuono (2016) find the variable tax planning and audit committee have a positive and significant effect on company value. Harventy (2016) states that tax avoidance affects company value. This study uses the annual cash ETR proxy as a tax avoidance proxy while the company value uses the Tobins' Q proxy.

Research conducted by Perdana (2014) revealed that tax planning using ETR proxies did not significantly influence firm value and book-tax difference had a positive effect on firm value, institutional ownership had a positive effect on firm value, independent board composition did not significantly influence firm value, and auditor quality has no effect on firm value.

Research conducted by Saputro (2011) about the effect of Book Tax Different on profit growth. The purpose of this study is to find empirical evidence 
related to Book Tax Different in the next period. The results of this study stated that Book Tax Different had a significant negative effect on profit growth for the next period.

Herdiyanto (2015) revealed that tax avoidance affects company value. Institutional ownership cannot moderate and agency costs cannot be intervening variables in the relationship between tax avoidance and firm value.

This research is the development of two studies, namely Ftouhi, Ayed, \& Zem-zem (2015) in Europe and Herawati \& Ekawati (2015) in Indonesia. The reason for using 2 studies is to complete the measurement tools for tax planning and corporate value.

Research conducted by Ftouhi, Ayed, \& Zemzem (2015) about tax planning and corporate value in Europe. 73 companies listed on the Euronext 100 index in the 2008-2012 period were used as samples. The tax planning measuring instrument used is Cash ETR and the company value measurement tool, Tobins'Q. The results obtained by tax planning negatively affect the value of the company due to higher agency costs.

Research conducted by Herawati \& Ekawati (2015) in Indonesia on tax planning on company value. The sample used is the financial statements of PT. Unilever Indonesia, Tbk from the period 2006 to 2015. Planning measures used include cash effective tax rates, long-run effective tax rates, different tax books, and tax sheltering activities while company values are measured using price earnings ratios. The results obtained show that Cash ETR and Long-run cash ETR do not affect the value of the company. As with the book-tax different (BTD) has a negative influence on the value of the company. In contrast to Tax shelters that have a positive impact on company value.

The difference in this study with Ftouhi, Ayed, \& Zemzem (2015) and Herawati \& Ekawati (2015) lies in the use of samples. This study uses a sample of manufacturing companies listed on the Indonesia Stock Exchange from 2016-2018. The independent variable used is tax planning with the measurement of Cash Effective Tax Rate (CETR) and Book tax different (BTD) adopted from Herawati \& Ekawati's research (2015) while the dependent variable is company value by using the Tobins' $Q$ formula adopted from the Ftouhi research, Ayed, \& Zemzem (2015).

\section{Theoritical Framework and Hypotheses Development}

Agency Theory

Agency theory involves managers (agents) and owners (principle) in a business process. In the opinion of Jensen \& Meckling (1976) a company is a collection of contracts (nexus of contracts) between (principal) and managers (agents) that handle the management and management of these resources. Between company owners (principal) and managers (agents), there will often be conflicts of interest, which can lead to information gaps. This explains that managers are more likely to manipulate information.

In this case, tax planning activities can be used as an opportunity for managers (agents) to benefit themselves (opportunism) by placing inappropriate resources and lacking transparency so that tax planning assumptions can have a negative impact on company value. This theory shows the importance of separation between the company owner (principal) and the manager (agent), to create efficiency and effectiveness in managing a company.

\section{Positive Accounting Theory (PAT)}

This theory explains the factors that influence management in determining accounting procedures optimally with specific objectives. According to this theory, the company is freed to determine accounting procedures to maximize the value of the company and minimize business costs (Yuliani, 21-22 June 2013).

\section{The Effect of Cash ETR on Company Value}

Cash ETR is used to describe tax planning activities, with the measurement of corporate tax planning can estimate the amount of tax to be deposited so that it will affect the company's value. Based on agency theory, managers (agents) who will take tax planning actions to reduce tax expenditures, this will cause an information gap between the manager (agent) and the company owner (Principal). According to previous studies Dyreng, Hanlon, \& Maydew (2008) stated that Cash ETR was used to describe all tax planning activities. Research conducted by Noviani (2017) also states that tax 
planning has a negative effect on firm value.

The greater the value of Cash ETR, the smaller the corporate tax planning and vice versa, the smaller the Cash ETR, the greater the corporate tax planning, with a large tax planning, it will affect the value of the company. It can be said that Cash ETR has a negative direction with company value. Based on this explanation, hypothesis 1a can be formulated as follows:

$\mathrm{H} 2$ : Cash ETR has a negative effect on firm value

\section{The Effect of Book Tax Difference on Company Value}

Book tax difference (BTD) is the difference between the amount of accounting income and tax revenue calculation of the average value of assets because BTD describes the tax payments made by the company. Based on agency theory, the manager (agent) will take tax planning actions in order to minimize the tax burden. Previous research according to Efendi (2014) if the profit according to accounting is greater than according to fiscal profit, the company carries out tax planning and if the profit according to accounting is smaller than according to fiscal profit, the company does not do tax planning.

The greater the difference in BTD, the lower the quality of profits generated will thus affect the decline in the value of the company. The smaller the BTD difference, the higher the tax planning, thus the company can minimize the amount of tax burden so that it will affect the amount of profit, it can be said BTD has a negative direction on the value of the company. The greater the company's profits, the value of the company produced will also be large. This means that tax planning that is measured, using BTD has a negative direction towards the value of the company. Based on the explanation that has been explained, then hypothesis $1 \mathrm{~b}$ namely:

$\mathrm{H} 2$ : Book tax difference has a negative effect on company value

Based on the explanation of the development of the hypothesis above, the research model is as follows:

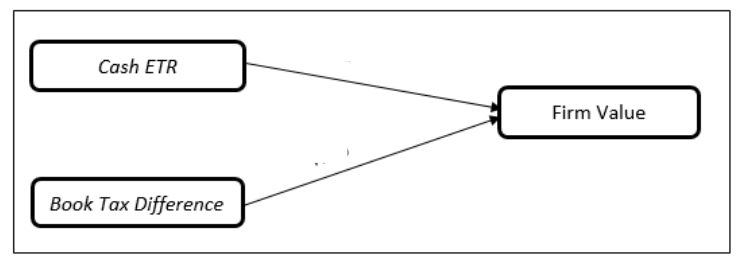

Figure 1. Research Model

\section{Research Methods}

Research The research method used is a quantitative approach because it tests the hypothesis. The reason the authors use a quantitative approach in this study is related to the source of the data used derived from secondary data in the form of annual reports and financial statements of manufacturing companies listed on the Stock Exchange from 2016 through 2018. The quantitative approach is carried out to be able to determine the relationship between variables in a population. The independent variable of this study is tax planning which is proxied by Cash ETR and BTD and the dependent variable is Company Value which is proxied by Tobins'Q. This study has 2 control variables, namely leverage, and company size (size).

\section{Dependent Variable - Tobins' $Q$}

In research, measuring company value is to use the Tobins' Q formula developed by Professor James Tobin. This ratio illustrates the estimated return on each investment. Tobins'Q compares the ratio of the market value of a company's stock to the book value of a company's equity. The researcher uses a formula which has been simplified by Smithers \& Wright (2007) as follows:

$$
\mathrm{Q}=\frac{(\mathrm{EMV}+\mathrm{D})}{(\mathrm{EBV}+\mathrm{D})}
$$

Source: (Smithers \& Wright, 2007)

\section{Independent Variable - Cash Effective Tax Rate (Cash ETR)}

Its independent variable is the CSR measured by the GRI indicator. According to The World Business Council for Suistanable Development (WBCSD) CSR is an effort to compensate for long-term and sustainable corporate survival through cooperation with several stakeholders. CSR is measured using the

Cash effective tax rate 1 (Cash ETR) is one of the measurement tools for short-term tax planning. Cash ETR is used to describe corporate tax avoidance activities (Dyreng, Hanlon, \& Maydew, 2008). Measurement with Cash ETR can answer the problems and limitations of measuring tax avoidance. Researchers write the formula for calculating the effective cash rate (Cash ETR) proposed by Hanlon \& Heitzman (2010) as follows: 


$$
\text { Cash ETR }=\frac{\text { Cash paid } i, t}{\text { Pretax income i,t }}
$$

Source: (Hanlon \& Heitzman,2010)

\section{Independent Variable - Book Tax Difference}

Book tax difference is the difference in the amount of profit in accounting calculations with profits calculated in taxation. Book tax difference is divided into 2 types, namely permanent difference and time difference. The difference still applies if a component is included in one of the old measurements, but not included in another profit measure. Can be interpreted as a component included in accounting profit, then the component is not included in the size of fiscal profit. This study uses the formula used by Weber (2008) as follows:

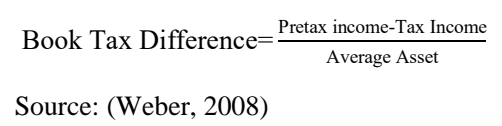

\section{Control Variables - Company Size}

Company size is a scale that is seen from the total assets of a company and total sales. The greater the assets, sales, and market capitalization, the greater the size of the company. The more assets, capital invested, sales, the more money turnover, and the greater the market capitalization, the greater the company is known by the public. This research measures company size by the natural logarithm of total sales (GarciaTeruel \& Martinez-Solano, 2007). Here's the formula:

Firm Size $=$ Ln TR

Source: (Garcia-Teruel \& Martinez-Solano, 2007)

\section{Control Variables - Leverage}

Leverage is used to measure the extent of purchases made with debt compared to capital and assess the ability to pay interest and other expenses (Fraser, 2019). Debt can have a positive or negative effect on a company's value because the benefits derived from the use of debt are less than the costs incurred.

$$
\begin{aligned}
& \text { Leverage }=\frac{\text { Total Debt }}{\text { Total Asset }} \\
& \text { Source: (Brigham \& Houston, 2010) }
\end{aligned}
$$

\section{Data Types and Sources}

Researchers use ratio data, intending to facilitate the analysis in research. Researchers use data in the form of numbers in the presentation of data reports and analyzed with statistical tests (Sugiyono, 2013). This study uses data sourced from the Indonesia Stock Exchange (IDX) in the form of a company's financial statements.

\section{Location and Research Objects}

Researchers took the object of manufacturing companies that are on the Indonesia Stock Exchange (IDX) starting in 2016-2018. The selection is based on the consideration that the Indonesia Stock Exchange has complete and up-to-date financial statement data. Data source comes from secondary data. The population obtained amounted to 163 companies that publish their financial statements to the general public.

\section{Sample Quantity Assignment Techniques}

The total population of this study is around 163 manufacturing companies. The number of samples will be obtained under the criteria imposed because the sampling technique is purposive sampling.

\section{Sample Quantity Withdrawal Technique}

This study uses a purposive sampling method where sampling is determined based on the characteristics or criteria of the study. Purposive sampling is chosen by the researcher as a technique for sampling because this technique divides the sample in specific criteria so that it can answer according to the research problem. The criteria for sampling are as follows:

1. Manufacturing companies listed in Indonesia Stock Exchange in 2016-2018.

2. Companies that use rupiah.

3. Companies that are not experiencing losses during 2016-2018.

4. Complete financial statements in order from 2016-2018.

\section{Data Collection Techniques}

Data collection techniques used in this study are secondary data that is archive data in the database. Data were obtained from the Indonesia Stock Exchange from 2016 through 2018. The database is used to make it easier for researchers to obtain data, so researchers do not need to go to every company to request financial reports that look forward to being research data. 


\section{Data Processing Techniques}

Data processing techniques used in this study according to (Sugiyono, 2013) include:

1. Editing

Editing is an activity of checking the data that has been collected, this activity is carried out to correct the data collected because it may be illogical or doubtful. At this stage, the researcher calculates the amount of data and completeness of the data in the financial statements following the research sample criteria.

2. Coding

At this stage, the researcher only converts the research variables into symbols so that they can facilitate data collection.

3. Tabulating

Tabulation is the stage to do the recording to make the required data with the help of tables. At this stage, researchers make a recapitulation of all data that has been obtained by inputting data into Microsoft Excel.

4. Statistical data processing

At this stage, the researcher processes the tabulated data using Eviews 9 software. The program has good capabilities and is suitable for supporting research.

\section{Data Analysis Technique}

This study uses panel data with the aim of the analysis to be more comprehensive because every year each sample can be represented and shows a historical relationship between the current year and the previous year. Panel data processing in this study uses the application Eviews 9. There are three techniques in determining estimation models according to Widarjono (2009) namely Common Effect or Pooled Least Square (PLS) Model, Fixed Effect Model Approach, and Random Effect Approach Model (Random Effect Model). To choose the most appropriate model among Common Effects, Fixed Effects, and Random Effects in managing panel data, it is necessary to carry out several tests as follows: Chow Test, Hausman Test, and Lagrange Multiplier (LM) Test.

\section{Results and Discussion}

\section{Description of Sample Research}

The object of research used in this study were all companies listed on the Stock Exchange for three consecutive years, namely from 2016 to 2018. Based on observations of financial statement data at www.idx.id, manufacturing companies registered in 2016 to 2018 were 163 companies. The selection of samples used is based on several criteria contained in chapter 3 . The initial samples used in the study were 163 companies, but some companies did not fit the criteria. So, the number of samples that fit the criteria is 45 companies per year (45 companies $\times 3$ years = 135 companies). The amount of sample data used can be seen in table 1 .

Table 1

Characteristics Sample

\begin{tabular}{lc}
\hline \multicolumn{1}{c}{ Description } & $\begin{array}{c}\text { Total of } \\
\text { Companies }\end{array}$ \\
\hline $\begin{array}{l}\text { Manufacturing Sector Companies listed on } \\
\text { the IDX from 2016-2018 }\end{array}$ & 163 \\
$\begin{array}{l}\text { Companies that use foreign currencies in } \\
\text { their financial statements }\end{array}$ & $(25)$ \\
Company data that suffered losses \\
$\begin{array}{l}\text { An incomplete company submits financial } \\
\text { statements }\end{array}$
\end{tabular}

\section{Descriptive Statistics}

Based on descriptive statistical tests in table 2, it can be seen that the amount of data used in this study was 135 sample data. The dependent variable in the form of company value is measured using the Tobins'Q (TQ) ratio, which is the market value of equity plus the book value of total debt divided by the book value of total assets plus the book value of total debt. The company value variable (TQ) with the lowest value of 0.3265 in 2016 is owned by PT Nusantara Inti Corpora Tbk and the highest value of 13.44883 in 2017 is owned by PT Unilever Indonesia Tbk and the standard deviation value between the lowest and highest value is 2.2659. The average value of 135 companies is 1.9467, which means the company's value is considered attractive because the Tobins'Q ratio is above one. The ratio value above the number one states that the market value is greater than the book 
value which means that the company has good prospects. Generally, investors will choose a company that has a Tobins'Q ratio above one number because it states that investment in assets provides a greater value than investment expenditure.

The independent variable is tax planning which is measured using Cash ETR (CETR) and Book Tax Different (BTD). CETR calculation uses a formula that is the amount of tax cash paid divided by income before tax. CETR has a minimum value of 0.0000 in 2018 owned by PT Indo Komoditi Korpora TBK and a maximum of 0.9852 in 2017 is owned by PT Star Petrochem TBK and a standard deviation value between the lowest and highest value of 0.1384 . The average value of 135 companies is 0.2779 . The company's average CETR value of $27.79 \%$ (in percentage) means that the average company used as a sample tends to take tax planning actions. It can be said that CETR is smaller than the company's effective tax rate of $28 \%$.

BTD calculations use the formula that is income before tax minus tax revenue divided average assets. BTD has a minimum value of 0.0013 in 2018 owned by PT Nusantara Inti Corpora TBK and a maximum of 34.8857 in 2016 owned by PT Kalbe Farma TBK and a standard deviation value between the lowest and highest values of 6.6952. The average value of 135 companies is 2.3037 so it can be identified that the results of research data used are very good because the standard deviation is a reflection of a very high deviation.

This study has two control variables namely company size (Size) and Leverage (LEV). The first control variable uses company value measured using the natural logarithm of total assets. The minimum company size variable of 5.6013 in 2016 is owned by PT Chitose International TBK and the maximum of 8.5229 in 2018 is owned by Astra International TBK and the standard deviation between the lowest and highest values is 0.6869 . The average value of the company size of 135 samples was 6.5634 . The size of the company size will affect the capital structure based on the fact that a company is getting bigger.

The second control variable uses leverage (LEV) which is measured using total debt divided by total assets. The variable leverage (LEV) with a minimum value of 0.0687 in 2016 owned by PT Garuda Metalindo TBK shows that the company's debt is very small so that the possibility of debt can be repaid with very large assets. Then the maximum value of 4.4879 in 2018 is owned by PT Charoen Pokphand Indonesia TBK which shows that the debt ratio of large companies so that the possibility of debt can be paid using assets is very small. The average value of the debt ratio of 135 companies is 0.5046 of total assets, which means the company can still cover the debt assets owned until the ratio is quite reasonable. The standard deviation value between the lowest value and the highest value is 0.6734 .

Table 2

Descriptive Statistic

\begin{tabular}{llllll}
\hline & N & Mean & Max & Min & Std.Dev \\
\hline TQ & 135 & 1.9467 & 13.4883 & 0.3265 & 2.2659 \\
CETR & 135 & 0.2779 & 0.9852 & 0.0000 & 0.1384 \\
BTD & 135 & 2.3037 & 34.8857 & 0.0013 & 6.6952 \\
SIZE & 135 & 6.5634 & 8.5229 & 5.6013 & 0.6869 \\
LEV & 135 & 0.5046 & 4.4879 & 0.0687 & 0.6734 \\
\hline Source: Eviews 9,2020 & & & &
\end{tabular}

\section{Data Analysis}

Based on the results of hypothesis testing between independent variables, control variables, and dependent variables, a summary of the results of the hypothesis test can be seen in Table 3 as follows:

Table 3

Statistical results $\mathrm{T}$ hypothesis

\begin{tabular}{lcrr}
\hline Variable & Expected & Coefficient & \multicolumn{1}{c}{ Sig. } \\
\hline C & & 12.5434 & $* * 0.0445$ \\
CETR (H1a) & - & 2.8996 & $* * * 0.0020$ \\
BTD (H1b) & - & -0.1362 & $* * 0.0191$ \\
SIZE & -1.7436 & $* 0.0570$ \\
LEV & 0.8258 & 0.1602 \\
R-squared & & 0.9500 \\
Adjusted R-squared & & 0.9220 \\
Prob(F-statistic) & & $* * * 0.0000$ \\
N & & 135 \\
Model Test & & Fixed \\
Results & & \\
\hline$* * *$ Significant 1\%. **Significant 5\%. *Significant 10\%. &
\end{tabular}

Source: Eviews 9, 2020

\section{The Effect of Cash ETR on Company Value}

Based on the results of testing hypothesis 1a which can be seen in Table 3 shows that Cash ETR does not have a negative effect on firm value but has a positive and significant effect so that hypothesis $1 \mathrm{a}$ is rejected. The first research result shows that the significant 
value of tax planning which is proxied by Cash ETR of 0.0020 is smaller than 0.05 , it means that tax planning has a significant positive effect on firm value. One way to identify the value of a company can use company shares, with high share prices, the level of welfare of shareholders is also high. The high share price can be obtained if the company can provide large dividends for shareholders. Large dividends come from large corporate profits, efforts to obtain large profits is by doing tax planning. By doing high tax planning the company will get high profits so that the value of the company will increase, so than that hypothesis 1a is not supported.

The results of this study stated that Cash ETR has a positive effect on company value, which means that the greater the tax planning proxied by Cash ETR, the greater the company's value. In this case, CETR is not in line with the research of Herawati \& Ekawati (2016) which states that Cash ETR has no effect on the value of the company because the tax rates paid are in accordance with the government tax rate rules. This study is in line with the research of Yuono (2016) which states that tax planning has a positive effect on firm value. A company with a high level of liquidity does not guarantee that the company will pay dividends. Corporate liquidity only evaluates the ratio between the company's current assets and current debt, but not dividend payments.

\section{The Effect of Book Tax Difference on Company Value}

Based on the results of testing the hypotheses that have been described in table 3 show that Book Tax Different has a negative effect on firm value. The second research result shows that the significant value of tax planning which is proxied by Book Tax Different of 0.0191 is smaller than 0.05 and the coefficient of -0.1362 means that tax planning has a negative effect on firm value. This is in line with research by Herawati \& Ekawati (2016) which states that Book Tax Different influences firm value.

This study states that Book Tax Different affects the value of the company. This statement of negative influence is caused by the market response which views that an increase in the total tax difference can increase the payment of corporate tax burden to reduce the amount of the company's net income which impacts on the amount of dividends to be received and ultimately has a negative effect on the value of the company. This is following the Positive Accounting Theory which states that earnings management behavior uses the Political Cost Hypothesis which means that taxes are withdrawn based on profits earned by the company, thus making managers act to process profits so that the tax paid is not too large. In other words, the smaller the Book Tax Different, the greater the value of the company that will be generated, so than that hypothesis $1 \mathrm{~b}$ is supported. The results of this study are not in line with research conducted by Saputro \& Zulaikha (2011) which states that Book Tax Different does not affect earnings growth.

Based on the results of testing the SIZE and Leverage (LEV) variables as control variables in this study that does not affect the firm value. That is because companies in funding their assets tend to use their capital from share capital and retained earnings rather than using debt. The use of excessive debt will reduce the benefits to be received but not worth the costs incurred. Therefore, large debt decreases the value of the company while low debt can increase the value of the company.

\section{Conclusions}

The purpose of this study was to determine the effect of proxied tax planning using Cash ETR and Book Tax Difference (BTD) on firm value. The result shows that Cash ETR has a positive and significant effect on firm value, this indicate that greater the tax planning, the greater the value of the company. Furthermore, Book Tax Different has a negative effect on firm value. This statement of negative influence is caused by the market response which views that an increase in the total tax difference can increase the payment of corporate tax burden to reduce the amount of the company's net income which impacts on the amount of dividends to be received and ultimately has a negative effect on the value of the company. There are some limitations in this study include the period of research observation is only limited to 3 years, namely 2016-2018, so the results cannot be generalized for the years before or afterward. There are quite a number of companies that do not display the full annual report so that it limits the number of companies that are sampled. The independent variables used are only 2 variables, while there are still many other factors that affect the value of the company and other measurements such as Tax Shelter, or others related to tax planning could not added in this research. Further research, can extend the time period, use samples other than manufacturing companies, and can use different measurements for firm value such as Price Earning Ratio (PER) and Price to Book Value (PBV). 


\section{References}

Brigham, \& Houston. (2010). Dasar-dasar Manajemen Keuangan Buku 1 (Edisi 11). Jakarta : Salemba Empat.

Dyreng, S., Hanlon, M., \& Maydew, E. (2008). Long-run corporate tax avoidance. The Accounting Review, 83 (1), 61-82.

Efendi, I. (2014). Analisis Pengaruh Perencanaan pajak (Tax Planning) Sebagai Upaya Untuk Menekan Beban Pajak Penghasilan Perusahaan Perbankan Yang Terdaftar Di Bursa Efek Indonesia Tahun 2011-2012. Skripsi. Universitas Muhammadiyah Surakarta.

Ftouhi, K., Ayed, A., \& Zemzem, A. (2015). Tax Planning and Firm Value: Efidence From European Companies. International Journal Economics \& Strategic Management of Business Process 2nd International Conference On Business, Economics, Marketing \& Mnagement Research (BEMM'14), 4, 73-78.

Garcia-Teruel, P. J., \& Martinez-Solano, P. (2007). Effects of working capital on SME profitability. International Journal of Managerial Finance, Vol. 3 Issue. 2, pp. 164-177.

Hanlon, M., \& Heitzman, S. (2010). A Review of Tax Research. Journal of Accounting, 127-178.

Harventy, G. (2016). Pengaruh Tax Avoindance terhadap Nilai Perusahaan . Jurnal Reviu Akuntansi, 895-906.

Herawati, \& Titin. (2013). Pengaruh Kebijakan Dividen, Kebijakan Hutang dan Profitabilitas Terhadap Nilai Perusahaan. Jurnal Manajemen, 1-18.

Herawati, H., \& Ekawati, D. (2016). Pengaruh Perencanan Pajak Terhadap Nilai Perusahaan. Jurnal Riset Akuntansi dan Keuangan, 873-884.

Herdiyanto, D. G. (2015). Pengaruh Tax Avoindace Terhadap Nilai Perusahaan . Semarang: Skripsi Fakultas Ekonomika dan Bisnis Universitas Diponegoro.

Hidayat, S. W., \& Pesudo, D. A. (2019). Pengaruh Perencanaan Pajak dan Kepemilikan Manajerial Terhadap Nilai Perusahaan dengan Transparansi Perusahaan Sebagai Variabel Moderasi. International Journal of Social Science and Business, 367-376.

Jensen, M. C., \& Meckling, W. H. (1976). Theory of the firm: Managerial Behavior, Agency Costs and Ownership structure. Journal of Financial Economics, 3, 305-360.Lestari, N. (2014). Pengaruh Tax Planning Terhadap Nilai Perusahaan. Akuntabilitas Vol. VII , 69-83.
Noerirawan, M. R. (2012). Pengaruh Faktor Internal dan Eksternal Perusahaan Terhadap Nilai Perusahaan. Diponegoro Journal of Accounting Vol 1, 1-12.

Noviani, A. S. (2017). Pengaruh Perencanaan Pajak, Manajemen Laba, dan Good Corporate Governance Terhadap Nilai Perusahaan. Jakarta: Skripsi Universitas Islam Negeri Syarif Hidayatullah.

Pandu, D., \& Achmad, T. (2017). Pengaruh Perencanaan Pajak Terhadap Nilai Perusahaan dengan Kualitas Corporate Governance sebagai Variabel Moderasi (Studi Empiris pada Perusahaan Manufaktur yang Terdaftar di BEI pada Tahun 2012-2014). Diponegoro Journal Of Accounting, 2337-3806.

Perdana, R. (2014). Pengaruh Perencanaan Pajak dan Mekanisme Corporate Governance terhadap nilai perusahaan. Yogyakarta: Skripsi Universitas Muhammadiyah.

Pohan, C. A. (2013). Manajemen Perpajakan "Strategi Perencanaan Pajak dan Bisnis". Jakarta: PT. Gramedia Pustaka Utama.

Saputro, A.N. (2011). Pengaruh Book Tax Differences Terhadap Nilai Perusahaan. Semarang: Universitas Diponegoro.

Smithers, A., \& Wright, S. (2007). Valuing Wall Street. McGraw Hill.

Sugiyono. (2013). Metode Penelitian Bisnis . Bandung: CV Alfabeta.

Sukmadinata, N. S. (2009). Metode Penelitian Pendidikan. Bandung: Rosda Karya.

Weber, D. (2008). Book-Tax Differences, Analysts' Forecast Errors, and Stock Returns". Working Paper. University of Connecticut.

Yuliani. (21-22 Juni 2013). Aktivitas Operasional Bank dan Implikasinya terhadap Kinerja Keuangan dengan Faktor Risiko sebagai Pemediasi (Studi pada Sektor Perbankan Go Public di Bursa Efek Indonesia). Jurnal Keuangan dan Perbankan, Vol.17, hlm. 362375.

Yuono , C. S. (2016). Pengaruh Perencanaan Pajak dan Corporate Governance Terhadap Nilai Perusahaan pada Perusahaan Otomotif yang Terdaftar di BEI. Jurnal Ilmu dan Riset Akuntansi, V, hlm. 111-13. 